\title{
The Enzymes of Polyporus squamosus, Huds.
}

\author{
BY
}

\author{
A. H. REginAld BUller, D.Sc., Ph.D., \\ Professor of Botany at the University of Manitoba.
}

F ROM an anatomical study of wood undergoing decay through the agency of Polyporus squamosus, evidence was obtained that various enzymes are excreted by the Fungus ${ }^{1}$. Thus the disappearance of starch, proteids, and cellulose from the wood suggests that the mycelium produces amylolytic, proteolytic, and cytolytic enzymes. The experiments recorded in this paper were made partly with the object of supplementing these anatomical observations, and partly in order to increase our knowledge of the occurrence of enzymes in the Hymenomycetes. A number of investigations upon the enzymes of Psalliota, Russula, Boletus, \&c., have been made by various observers ${ }^{2}$, but little is known about those of the large tree-Fungi. Most of the latter belong to the genus Polyporus. Many of them are unsuitable for enzyme investigations owing to the tough or woody nature of their tissues. This, however, is not the case with Polyporus sulphureus and Polyporus squamosus. The former has bulky and very juicy fruit-bodies. Bourquelot and Hérissey ${ }^{3}$ have taken advantage of this fact, and have given us an account of the enzymes present in them.

Polyporus squamosus is one of the largest and commonest of British Polyporei. Its ochraceous fruit-bodies, often a foot across and splashed with brown scales above, are frequently to be seen projecting in the form of brackets, either singly or several together, upon the Sycamore, the Horsechestnut, the Elm, the Ash, and various other deciduous trees in woods, parks, and gardens. When the fruit-bodies are young they are soft and juicy, and an extract can be made from them with ease. This extract has been tested altogether for thirteen different enzymes. The investigation has afforded evidence that at least eight or nine are present in the fruitbodies.

Fresh young fruit-bodies were obtained, as required, from a tree at the

1 Buller, Polyporus squamosus as a timber-destroying Fungus, Journ. of Econ. Biol., vol. i, No. 2 (in the press), 1906.

${ }^{2}$ For literature see Reynolds Green, Fermentation, Cambridge, 1899.

3 Bourquelot et Hérissey, Les ferments solubles de Polyporus sulphureus, Bull. de la Soc. Mycol. de France, t. x, $4^{\mathrm{e}}$ fasc., I895, p. 235.

[Annals of Botany, Vol. XX. No. LXXVII. January, 1906.] 
Botanical Gardens, Birmingham, and their juice extracted. The extract, except where stated otherwise, was made from living and sound fruit-bodies directly before each experiment. One hundred grams of the Fungus were cut up into thin slices and then pounded in a mortar with Ico c.c. water for about forty minutes. The mixture was filtered through a cloth, this being folded over the residue and twisted, so as to extract as much juice as possible. The amount of the extract from a given weight of a fruit-body was fairly constant. One example will suffice. From $100 \mathrm{gm}$. Fungus plus 100 c.c. water, I 36 c.c. of liquid were extracted. The extract was light in colour and neutral in reaction.

(I) Amylase (diastase). In testing for this enzyme I c.c. of the extract was added to about 20 c.c. of a 5 per cent. solution of Lintner's soluble starch in a test-tube $a$. As a control experiment a similar mixture was made in a test-tube $b$, the extract, however, being first boiled. The tubes were kept at a temperature of $28^{\circ} \mathrm{C}$.

After sixteen hours 5 c.c. of the solution in $a$ was added to 5 c.c. of Fehling's solution and boiled for ten minutes. The Fehling's solution was thereby almost completely reduced, the blue colour practically disappearing and a large precipitate of cuprous oxide being thrown down. The control was tested in a similar manner when it was found that the colour of the Fehling's solution remained unchanged. Only the minutest trace of cuprous oxide was thrown down, doubtless due to some substance in the original extract, for this was found to have a very slight reducing action immediately after it was made. The complete hydrolysis of the starch in the test-tube $a$ was confirmed by the gradual disappearance of the blue reaction on testing with iodine.

Bourquelot and Hérissey (loc. cit.) demonstrated the presence of diastase in Polyporus sulphureus so that it was almost to be expected that Polyporus squamosus would contain a similar enzyme.

(2) Laccase. To determine the presence of laccase, 5 c.c. of the extract was added to Io c.c. of a 5 per cent. hydroquinone solution in a 50 c.c. flask $a$ stoppered with cotton wool. A similar mixture was made as a control in a flask $b$, the extract, however, being first boiled. The flasks were kept at the temperature of the laboratory.

After three hours the liquid in flask $a$ had assumed a distinct rose-tint and after eighteen hours was deep brownish red. During the next few days the colour gradually deepened. An iridescent pellicle consisting of green crystalline scales of quin-hydrone, with a metallic lustre, appeared on the surface of the fluid, and a dark red precipitate of the same substance was thrown down. There was a distinct smell of quinone. In the control the mixture was practically colourless after eighteen hours. Although within the next fourteen days the colour of the fluid darkened, no iridescent pellicle, dark red precipitate or smell of quinone was developed. 
Buller.-The Enzymes of Polyporus squamosus, Huds. $5 \mathrm{I}$

These experiments indicate that the fruit-bodies contain the oxydase called laccase.

(3) Tyrosinase. To 5 c.c. of the extract was added Io c.c. of a saturated solution of tyrosin in a 50 c.c. flask $a$, stoppered with cotton wool. A control was made in the same manner in a flask $b$, the extract, however, being first boiled. The temperature was that of the laboratory. Toluol was used as an antiseptic.

At the end of sixteen hours the contents of flask $a$ were found to have turned a deep black, and after thirty-six hours a very deep black. The control remained colourless.

As it seemed just possible that the black colour in the flask $a$ might have been produced by the oxidation of some substance in the extract, and not of the tyrosin, a second control was made. To 5 c.c. of the extract was added Io c.c. water in a flask $c$. After sixteen hours the mixture had turned brownish but not nearly so dark as that in flask $a$. By comparing this result with that obtained in $b$ we may conclude that the extract contains some substance which on oxidation (probably by means of an oxydase) becomes dark coloured.

The above experiments indicate that the fruit-bodies contain the oxydase called tyrosinase.

(4) Protease. The Fungus extract was tested upon gelatine, fibrin, and Witte peptone. To a solution of 7 per cent. unneutralized gelatine in a test-tube $a, 2$ c.c. of the extract were added. A similar preparation was made as a control in a test-tube $b$, the extract, however, being first boiled. A spot of toluol was added to each tube. The temperature was that of the laboratory.

After twenty-two hours the jelly in $a$ was found to be liquefied to a depth of $3 \mathrm{~mm}$., and after thirty-two hours to $6 \mathrm{~mm}$. No liquefaction occurred in the control.

Similar experiments were made with broth-gelatine containing 10 per cent. gelatine and 0.2 per cent. carbolic acid. There was a gradual liquefaction of the gelatine as a result of the action of the extract. In the control no liquefaction took place.

When pure cultures of the mycelium were made upon malt-wort extract solidified with 10 per cent. gelatine gradual liquefaction of the latter took place.

The above experiments leave no doubt that Polyporus squamosus produces an enzyme which liquefies gelatine.

Since the exact chemical nature of gelatine does not seem to be very clear, it was thought well to test the Fungus extract upon such undoubted proteids as fibrin and Witte peptone.

Upon fibrin the extract appeared to have no digestive action whatever. Ten grams of the dried Fungus chips were extracted with Ioo c.c. water. 
The extract was added to fibrin in test-tubes. The latter were then shaken up and set in a warm bath at $40^{\circ} \mathrm{C}$. After two days the fibrin had undergone no apparent digestion. The following table gives fuller details of the experiment.

TABLE I.

\begin{tabular}{|c|c|c|c|c|c|c|c|}
\hline & No. & Extract. & Fibrin. & Antiseptic. & $\begin{array}{c}\text { Acid or } \\
\text { alkali added. }\end{array}$ & $\begin{array}{l}\text { Special } \\
\text { treatment. }\end{array}$ & Result. \\
\hline$\left\{\begin{array}{l}\text { Experiment } \\
\text { Control }\end{array}\right.$ & $\begin{array}{l}\text { I } \\
2\end{array}$ & $\begin{array}{c}20 \text { c.c. } \\
,,\end{array}$ & $\begin{array}{c}0.5 \mathrm{gm} . \\
,\end{array}$ & $\begin{array}{c}0.25 \text { c.c. toluol } \\
,,\end{array}$ & $\begin{array}{c}\text { none } \\
,,\end{array}$ & extract boiled. & \\
\hline$\left\{\begin{array}{l}\text { Experiment } \\
\text { Experiment } \\
\text { Control }\end{array}\right.$ & $\begin{array}{l}3 \\
4 \\
5\end{array}$ & $\begin{array}{c}\text { IO c.c. } \\
, \\
,\end{array}$ & $\begin{array}{c}0.5 \mathrm{gm} . \\
, \\
,\end{array}$ & $\begin{array}{c}0.25 \text { c.c. toluol } \\
, " \\
, "\end{array}$ & $\begin{array}{l}5 \text { c.c. of a } \\
\text { o. } 5 \text { per cent. } \\
\text { sodium car- } \\
\text { bonate solu- } \\
\text { tion. }\end{array}$ & $\begin{array}{c}- \\
- \\
\text { extract boiled. }\end{array}$ & 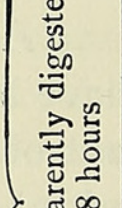 \\
\hline$\left\{\begin{array}{l}\text { Experiment } \\
\text { Experiment } \\
\text { Control }\end{array}\right.$ & $\begin{array}{l}7 \\
8\end{array}$ & $\begin{array}{l}", \\
5 \text { c.c. }\end{array}$ & $\begin{array}{c}0.5 \mathrm{gm} . \\
, \\
0.25 \mathrm{gm} .\end{array}$ & $\begin{array}{l}0.25 \text { c.c. toluol } \\
\text { O.I } 25 \text { c.c. toluol }\end{array}$ & $\left.\begin{array}{c}5 \text { c.c. of a } \\
0.2 \text { per cent. } \\
\text { hydrochloric } \\
\text { acid solution. } \\
\text { one half the } \\
\text { above } \\
\text { amount. }\end{array}\right\}$ & extract boiled. & 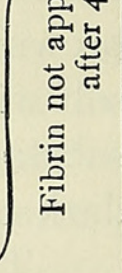 \\
\hline
\end{tabular}

According to Vines ${ }^{1}$ a certain vegetable protease is so constituted that, whilst it is unable to break down the albumens, it yet has the power to bring about the hydrolysis of albumoses and peptones. Such an enzyme he calls erepsin. The extract of Polyporus squamosus appears to act in this way. The tests for hydrolysis were made upon Witte peptone in Nessler tubes at a temperature of $40^{\circ} \mathrm{C}$. in accordance with the methods of Vines. The following table gives particulars of the experiments.

\section{TABLE II.}

\begin{tabular}{|c|c|c|c|c|c|c|}
\hline & \multirow{2}{*}{ No. } & \multirow{2}{*}{ Fungus. } & \multirow{2}{*}{$\begin{array}{l}\text { Witte } \\
\text { peptone. }\end{array}$} & \multirow{2}{*}{$\begin{array}{c}\text { Special } \\
\text { treatment. }\end{array}$} & \multicolumn{2}{|c|}{ Results with iodine after } \\
\hline & & & & & I5 hours. & 39 hours. \\
\hline $\begin{array}{l}\text { Experiment } \\
\text { Control. . }\end{array}$ & $\begin{array}{l}2 \\
3\end{array}$ & $\begin{array}{l}\text { extract from } \\
2 \text { gm. of dried } \\
\text { Fungus chips } \\
\text { made up to } \\
50 \text { c.c. with } \\
\text { water. }\end{array}$ & $0.3 \mathrm{gm}$ & $\begin{array}{c}\text { I.5 c.c. of a } \\
4 \text { per cent. } \\
\text { hydrocyanic } \\
\text { acid solution. } \\
\text { none. } \\
\text { extract boiled. }\end{array}$ & $\begin{array}{c}\text { ", } \\
\text { no violet colour. }\end{array}$ & $\begin{array}{c}\text { very distinct } \\
\text { violet ring. } \\
\text { no violet colour. }\end{array}$ \\
\hline $\begin{array}{l}\text { Experiment } \\
\text { Control. }\end{array}$ & $\begin{array}{l}5 \\
6\end{array}$ & $\begin{array}{l}2 \text { gm. of dried } \\
\text { Fungus chips } \\
\text { to which were } \\
\text { added } 50 \text { c.c. } \\
\text { of water. }\end{array}$ & $0.3 \mathrm{gm}$. & $\begin{array}{c}\text { I.5 c.c. of a } \\
4 \text { per cent. } \\
\text { hydrocyanic } \\
\text { acid solution. } \\
\text { none. } \\
\text { Fungus chips } \\
\text { boiled. }\end{array}$ & $\begin{array}{c}\text { no violet } \\
\text { precipitate. }\end{array}$ & $\begin{array}{c}\text { very distinct } \\
\text { violet } \\
\text { precipitate. } \\
\text {, } \\
\text { no violet } \\
\text { precipitate. }\end{array}$ \\
\hline
\end{tabular}

1 The Proteases of Plants, Ann. of Bot., vol. xix, I905, pp. I 7 I-87. 
The results in the above table indicate that the Fungus extract is capable of breaking down Witte peptone so that the products give the reaction for tryptophane. We may therefore conclude that the Fungus extract contains a protease which, according to Vines, may be considered to be an erepsin.

Bourquelot and Hérissey (loc. cit.) found a feebly proteolytic enzyme in Polyporus sulphureus. In respect to this enzyme, then, Polyporus squamosus behaves similarly.

(5) Emulsin.

TABLE III.

\begin{tabular}{|c|c|c|c|c|c|c|c|}
\hline & \multirow{2}{*}{ No. } & \multirow{2}{*}{ Extract. } & \multirow{2}{*}{$\begin{array}{l}\text { Amygdalin } \\
5 \text { per cent. }\end{array}$} & \multirow{2}{*}{ Antiseptic. } & \multicolumn{2}{|c|}{ Prussian blue reaction after } & \multirow{2}{*}{$\begin{array}{l}\text { Smell after } \\
40 \text { hours. }\end{array}$} \\
\hline & & & & & 23 hours. & 40 hours. & \\
\hline Experiment & I & I c.c. & 5 c.c. & toluol & $\begin{array}{l}\text { distinct } \\
\text { green }\end{array}$ & $\begin{array}{l}\text { distinct green fol- } \\
\text { lowed by a blue } \\
\text { precipitate. }\end{array}$ & $\begin{array}{l}\text { strong of } \mathrm{HCN} \text { and } \\
\text { benzoic aldehyd. }\end{array}$ \\
\hline Experiment & 2 & I c.c. & 5 c.c. & benzene & $\begin{array}{l}\text { very faint } \\
\text { green }\end{array}$ & $\begin{array}{l}\text { faint green followed } \\
\text { by light blue pre- } \\
\text { cipitate. }\end{array}$ & $\begin{array}{l}\text { distinctly of } \mathrm{HCN} \\
\text { and benzoic alde- } \\
\text { hyd. }\end{array}$ \\
\hline Control. & 3 & $\begin{array}{l}\text { I c.c. } \\
\text { boiled. }\end{array}$ & 5 c.c. & toluol & yellow & $\begin{array}{l}\text { yellow: no trace of } \\
\text { blue. }\end{array}$ & none. \\
\hline
\end{tabular}

The particulars of the experiments, made in test-tubes at about $18^{\circ} \mathrm{C}$ are embodied in the above table. The Prussian blue and smell tests clearly indicate that the fruit-bodies contain an emulsin enzyme.

(6) Rennetase. To 10 c.c. of fresh milk 2 c.c. of Fungus extract were added in a test-tube $a$. The control was made in a similar manner, the extract, however, being first boiled. The tubes were placed at a temperature of $28^{\circ} \mathrm{C}$.

After forty-five minutes the contents in $a$ had coagulated, whereas in the control there was no coagulation at all.

A few grams of a fruit-body, which had been carefully dried in thin slices, were pounded up with water and sand. The extract was forced through a cloth. Similar experiments to those just described were then made.

Clotting of the milk was seen to have begun fifteen minutes after the beginning of the experiment. At the end of two hours there was a solid plug at the top of the tube. The control remained unclotted.

The above experiments clearly prove that the fruit-bodies contain a rennetase.

(7) Lipase. The extract from $100 \mathrm{gm}$. of the Fungus pounded up with Ico c.c. water was $\mathrm{I} 64$ c.c. The tests were made upon a solution of $\mathrm{I} \cdot 84$ per cent. ethyl acetate. The 50 c.c. flasks employed were corked and placed in 
a warm chamber at $28^{\circ} \mathrm{C}$. Litmus solution was used for determining neutrality. The other details of the experiments are given in the table.

TABLE IV.

\begin{tabular}{|c|c|c|c|c|c|c|c|}
\hline \multirow[b]{3}{*}{ Experiment } & \multirow{3}{*}{$\begin{array}{c}\text { Acetate } \\
\text { solution. }\end{array}$} & \multirow{3}{*}{$\frac{\text { Extract }}{\text { io c.c. }}$} & \multirow{3}{*}{$\frac{\text { Toluol. }}{0.5 \text { c.c. }}$} & \multicolumn{4}{|c|}{$\begin{array}{l}\text { Amount of } \frac{1}{20} \text { normal KHO solution in c.c. } \\
\text { required for neutralizing Io c.c. after }\end{array}$} \\
\hline & & & & 40 hours. & 5 I hours. & 93 hours. & 330 hours. \\
\hline & & & & $3 \cdot 8$ & I I.06 & I $5 \cdot 5$ & I $8 \cdot 4$ \\
\hline \multirow[t]{2}{*}{ Control } & 40 c.c. & $\begin{array}{l}\text { Io c.c., } \\
\text { boiled }\end{array}$ & 0.5 c.c. & 0.14 & 0.12 & O.I 5 & 0.3 \\
\hline & & & & $\begin{array}{l}\text { after } \\
40 \text { hours. }\end{array}$ & $\begin{array}{l}\text { after } \\
51 \text { hours. }\end{array}$ & $\begin{array}{l}\text { after } \\
93 \text { hours. }\end{array}$ & $\begin{array}{l}\text { after } \\
330 \text { hours. }\end{array}$ \\
\hline \multicolumn{4}{|c|}{$\begin{array}{l}\text { Excess KHO in experiment over control by } \\
\text { subtraction } \\
.\end{array}$} & $3 \cdot 66$ & 10.94 & I $5 \cdot 35$ & I 8. I \\
\hline \multicolumn{4}{|c|}{$\begin{array}{l}\text { Grams of ethyl acetate bydrolyzed in Ioc.c. } \\
\text { by calculation }\end{array}$} & $0.016 I$ & $0.0+8 I$ & $0.063 \mathrm{I}$ & 0.0796 \\
\hline
\end{tabular}

It is evident from the results given in the above table that the ethyl acetate underwent continual hydrolyzation, 43 percent. thus becoming split up in $33^{\circ}$ hours. In the control there was practically no hydrolyzation. The presence of a lipase in the Fungus extract is thus made highly probable. It must not be forgotten, however, that a lipase is an enzyme, which splits up fats, and not necessarily such esters as ethyl acetate. It is as yet not absolutely certain that such an alcohol as ethylic can replace glycerine in the molecule so as to be acted upon in the same manner by lipase. Provisionally, however, it seems to me best to retain the name lipase for those enzymes which have the power of splitting up such compounds as ethyl acetate.

It may here be mentioned that when spores of Polyporus squamosus are allowed to dry for several days, many of them develop large fat-drops. On germination of the spores in malt-wort extract these drops disappear. Perhaps this is due to the action of a lipase.

(8) Pectase. The juice was squeezed out of fresh, ripe, red currants, filtered, then boiled and refiltered. Excess of alcohol was added to precipitate the pectin. This was then filtered as dry as possible with the aid of a suction filter. Water was then added to dissolve the pectin and the solution placed on a warm bath to drive off the alcohol. This solution was then used in testing for pectase.

The following were preliminary experiments to assure myself that the solution contained pectin. To I c.c. freshly extracted carrot-juice, which is known to contain pectase, 5 c.c. of the pectin solution were added in a 
porcelain dish $a$. In a control experiment, made similarly, I c.c. of water was used instead of the carrot-juice.

After five hours the contents of the dish $a$ had clotted into a single lump whereas the control remained unchanged. The experiments indicate that the solution prepared from the currants does contain pectin which can be clotted by pectase.

Experiments were then made with the extract of Polyporus squamosus. Of the pectin solution 25 c.c. were neutralized with $\frac{1}{20}$ normal potassium hydroxide solution and a few drops of a calcium chloride solution added. To 5 c.c. of the resulting solution I c.c. of the fresh Polyporns extract was added in a porcelain dish. A control was made in a similar manner, the Polyporus extract, however, being first boiled.

The result was negative. During the course of several days no clotting whatever occurred.

It was then thought that a pectase might possibly be present in the fresh Fungus in such a manner as not to be easily extracted, whereas it might be obtained from fruit-bodies which had undergone desiccation. Slices of the fresh Fungus were therefore dried over sulphuric acid in vacuo. The dry chips were then pounded up with water and an extract obtained. Experiments similar to those described with the extract from the undried Polyporus were then made.

The results were again entirely negative. No clotting occurred. In a control experiment made at the same time, in which carrot-juice was used instead of the Polyporus extract, clotting began in the course of two hours and was completed in 3.5 hours.

The above experiments leave little doubt that the fruit-bodies of Polyporus squamosus do not contain a pectase enzyme.

(9) Invertase. To 50 c.c. of a 5 per cent. solution of cane-sugar 5 c.c. of the Fungus extract were added in a test-tube $a$. A drop of toluol was used as an antiseptic. A control was made in a similar manner in a test-tube $b$, the extract, however, being first boiled. Both tubes were placed at a temperature of $29^{\circ} \mathrm{C}$.

After twenty-four hours 5 c.c. from each tube were boiled with 5 c.c. freshly made Fehling's solution. In each case there was a very slight reduction of copper sulphate.

After forty-eight hours the same test was again tried and a similar result obtained. There was only a very slight precipitate in each case, thus indicating that the extract had not brought about any inversion of the cane-sugar.

Similar experiments were made with an extract from carefully dried chips of the fruit-bodies. The results, however, were again negative.

The above experiments leave little doubt that the fruit-bodies do not contain invertase. Here, again, the conditions are similar to those in Poly- 
porus sulphureus, for Bourquelot and Hérissey (loc. cit.) were unable to detect the enzyme in that species.

(Io) Maltase. One gram of dried slices of the Fungus were well rubbed up with sand and a little of a 2 per cent. maltose solution. Of this mixture half by weight was put into each of two Ioo c.c. flasks which were then filled up to the Ioo c.c. mark with 2 per cent. maltose. The contents of one flask were boiled in order to make a control experiment. One c.c. toluol was used as an antiseptic in each case. The flasks were placed in a warm chamber at $29^{\circ} \mathrm{C}$.

At the end of three days 25 c.c. were removed from each flask, mixed with aluminium hydrate, and then filtered. The clear solutions thus obtained were then tested in the polarimeter. The readings were almost identical.

The experiments indicate that the fruit-bodies do not contain maltase.

(I1) Trehalase. Some trehala manna was obtained for me by Professor Adrian Brown through the kindness of the Pharmaceutical Society: From the manna a small amount of trehalose was prepared. The Fungus extract was made by rubbing up 5 grams of the dried fruit-bodies with 50 c.c. of water.

To Io c.c. of a 3 per cent. trehalose solution I c.c. of extract was added. A polariscope reading was then taken. Further polariscope readings were taken at intervals for three days, but no change was observed. The experiment, therefore, seems to indicate that no trehalase is present in the Fungus extract. However, Bourquelot and Hérissey (loc. cit.) found that this enzyme is present in the fruit-bodies of Polyporus sulphureus. It is, therefore, somewhat surprising that Polyporus squamosus does not seem to contain it.

(I2) Cytase. As a preliminary experiment and control $20 \mathrm{gm}$. of oats, which are known to contain cytase, were ground up, mixed with water, and after two hours filtered. The extract was then allowed to act on thin sections of barley-grains which had been cleared of starch in the course of twenty-four hours by means of saliva. The sections were watched in hanging drops under the microscope ${ }^{1}$. After two hours the cellulose walls of the sections were seen to be swelling and dissolving away, proving that a cytase had been extracted from the oats.

Similar experiments were made with a Polyporus extract, but with negative results, so that I was unable to prove the presence of a cytase in the fruit-bodies. Owing to the disappearance of cellulose from the walls of the cells in the wood of the Sycamore under the action of the Fungus ${ }^{2}$ there can, however, be little doubt that the vegetative part at least produces abundant cytase.

(13) 'Coagulase.' According to the recent work of Wolff and 1 See Marshall Ward, A Lily Disease, Ann. of Bot., vol. ii, 1888. 2 Buller, loc. cit. 
Fernbach ${ }^{1}$, malt contains an enzyme capable of causing the precipitation of starch from solution. It seemed to me of interest to test for the supposed new enzyme in the Fungus extract.

Ten grams of some dried chips of fruit-bodies were ground up with 100 c.c. water and an extract made. Soluble starch was then prepared by gelatinizing $50 \mathrm{gm}$. potato starch in 1000 c.c. boiling water and by then subjecting the mixture to a pressure of about two atmospheres for two hours in an autoclave. The experiments were made in tall 50 c.c. glass jars.

TABLE V.

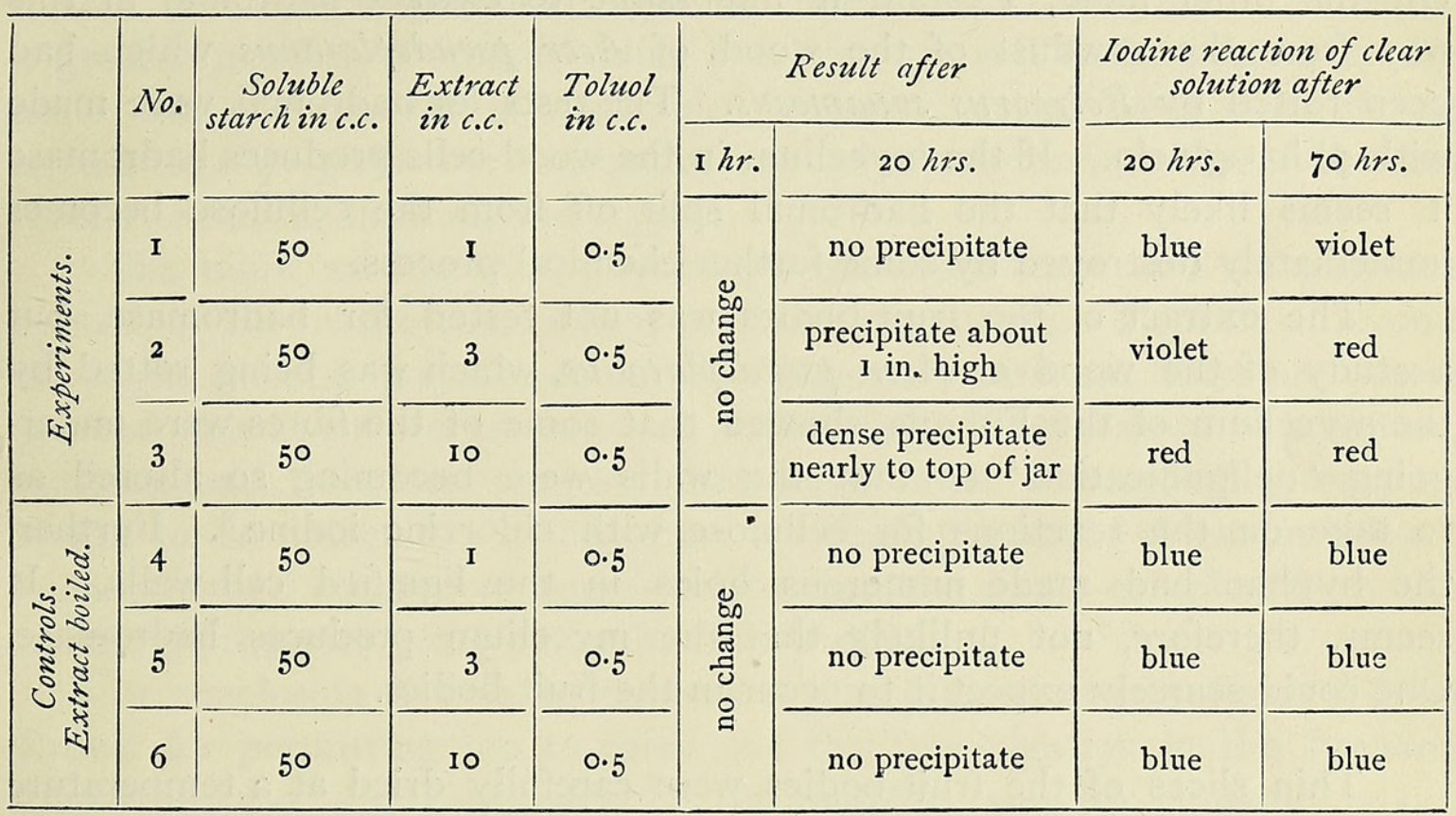

The above table gives an account of the experiments and the results. The white precipitate produced as a result of the action of the extract on the soluble starch gradually settled down, leaving a clear solution above. The precipitate, which under the microscope was found to consist of small particles, stained a deep blue with iodine. Exactly similar results were obtained in a set of experiments made like those described in the table but without the use of toluol. These results closely agree with those obtained in some preliminary experiments by acting upon soluble starch with malt extract under the conditions employed by Wolff and Fernbach ${ }^{2}$. If the starch precipitate is due to a special enzyme, coagulase, there is, therefore, reason to believe that the latter is present in the Fungus extract.

The clear solution above the starch precipitate was tested with iodine. In the course of the experiments the clear solution was found

\footnotetext{
1 Wolff u. Fernbach, Compt. rend., Nov. 2, 1903.

${ }^{2}$ loc. cit.
} 
to change its reaction gradually from blue to red, indicating the formation of erythro-dextrin. We thus have another proof of the presence of an amylase in the extract.

(I4) Hadromase. According to Czapek, Merulius lacrimans and certain other wood-destroying Fungi produce an enzyme which he has called hadromase, and which is capable of splitting hadromal from cellulose $^{1}$. He regards these bodies as being united in an ether-like compound in lignified membranes ${ }^{2}$.

In the case of Merulius lacrimans the hadromal does not appear to be destroyed, for it can be dissolved out of rotted wood with alcohol, $\&$ c., in considerable quantities after the cellulose has practically disappeared. On the other hand, I found it impossible to extract hadromal in this way from the sawdust of the wood of Acer pseudoplatamus which had been rotted by Polyporus squamosus. The tests for hadromal were made with phloroglucin. If the mycelium in the wood-cells produces hadromase it seems likely that the hadromal split off from the cellulose becomes immediately destroyed by some further chemical process.

The extract of the fruit-bodies was not tested for hadromase, but a study of the wood of Acer pseudoplatamus, which was being rotted by the mycelium of the Fungus, showed that some of the fibres were undergoing 'delignification' or that the walls were becoming so altered as to take on the reactions for cellulose with chlorzinc iodine ${ }^{3}$. Further, the hyphae had made numerous holes in the lignified cell-walls. It seems, therefore, not unlikely that the mycelium produces hadromase. One could scarcely expect it to occur in the fruit-bodies.

Thin slices of the fruit-bodies were carefully dried at a temperature of about $80^{\circ} \mathrm{C}$. and preserved in a well-stoppered bottle. After nine months, tests were again made for some of the enzymes. The extract from this preserved material appeared to be just as active as that made from the same material when it was first dried. Thus milk was clotted in fifteen minutes, an $\mathrm{C} \cdot 2$ per cent. Lintner's starch solution underwent complete hydrolysis in three hours, and gelatine was liquefied about as rapidly as in the first experiments. I have, therefore, found the material well suited for experiments by students in the laboratory.

Kohnstamm ${ }^{4}$ states that he found an amylase, emulsin, and a protease in the fruit-bodies of Polyporus squamosus. His material, however, was

1 Czapek, Zur Biologie der holzbewohnenden Pilze, Ber. d. D. Bot. Gesell., Bd. xvii, I899, p. 166.

${ }^{2}$ Czapek, Ueber die sogenannten Ligninreactionen des Holzes. Zeitschrift für physiologische Chemie, Bd. xxvii, I899, p. I4.

${ }^{3}$ Buller, loc. cit.

4 Amylolytische, glycosidspaltende, proteolytische und Cellulose-losende Fermente in holzbewohnenden Pilzen. Beih. z. Bot. Centralbl., Bd. x, I901, p. 90. 
collected in January and March. As fruit-bodies which have hung on trees through the winter are always dead and usually worm-eaten and attacked by saprophytic Fungi, a confirmation of his results with fresh and perfectly sound material, as given in this paper, seemed to me highly desirable.

My work has shown that the following enzymes occur in the fruitbodies of Polyporus squamosus: laccase, tyrosinase, amylase, emulsin, a protease, lipase, rennetase, and 'coagulase'; whereas negative results were obtained in the tests for pectase, maltase, invertase, trehalase, and cytase. A study of the destruction of the wood of the Sycamore (Acer pseudoplatamus $^{1}$ ) points to the conclusion that the mycelium produces cytase and possibly also hadromase. Altogether, then, we may take it that the Fungus produces eight or nine different enzymes. Whether a greater number of these bodies has been proved to be present in any other single organism is doubtful. However, seven have been shown to exist in Aspergillus by Bourquelot ${ }^{2}$, namely, invertase, maltase, trehalase, inulase, emulsin, diastase, and trypsin.

The more we know of physiology the more important do enzymes appear to be in the metabolism of living organisms. Doubtless beyond the eight or nine enzymes found in Polyporus squamosus there are others present with which we are not yet acquainted. The absence of invertase, maltase, and trehalase suggests that some other corresponding enzyme is still to be detected. In any case a sufficient number of enzymes have been recorded to give us some insight into the great complexity of the chemical processes going on in the fruit-bodies.

In conclusion I wish to express my best thanks to Professor Adrian Brown for permitting me to carry out this investigation in the Brewing Department of the University of Birmingham, and for valuable advice in connexion with the tests for the enzymes.

1 Buller, loc. cit.

2 Bull. Soc. Mycol., I893, p. 23 I. 


\section{$2 \mathrm{BHL}$ Biodiversity Heritage Library}

Buller, A. H. Reginald. 1906. "The enzymes of Polyporus squamosus, Huds." Annals of botany 20, 49-59.

https://doi.org/10.1093/oxfordjournals.aob.a089082.

View This Item Online: https://www.biodiversitylibrary.org/item/234848

DOI: https://doi.org/10.1093/oxfordjournals.aob.a089082

Permalink: https://www.biodiversitylibrary.org/partpdf/318821

\section{Holding Institution}

Smithsonian Libraries

\section{Sponsored by}

Biodiversity Heritage Library

\section{Copyright \& Reuse}

Copyright Status: Not in copyright. The BHL knows of no copyright restrictions on this item.

This document was created from content at the Biodiversity Heritage Library, the world's largest open access digital library for biodiversity literature and archives. Visit BHL at https://www.biodiversitylibrary.org. 